Artikel Penelitian

\title{
Kinetika Adsorpsi Cangkang Telur pada Zat Warna Metilen Biru
}

\author{
Lailatul Badriyah*, Mardiana Prasetyani Putri \\ Jurusan Kimia, Institut IImu Kesehatan Bhakti Wiyata, Kediri, Indonesia
}

\section{INFO ARTIKEL}

Sejarah artikel:

Revisi 09 Maret 2017

Diterima 30 Maret 2017

Tersedia online 09 Mei 2017

*Penulis korespondensi

Email: blailatul@gmail.com

\section{ABSTRAK}

Methylene blue was one of the dyes which used in industry. It is an organic compound that dangerous and could disturb biota aquatic if it throws away in the river without preparation. Hence, it needs a treatment in liquid dye waste that could reduce degree of dye. The aim was to analyse reaction kinetic of methylene blue adsorption by egg shell. One of the treatments was adsorption. Synthesized egg shell were analysed by using FTIR to know some function groups. The reaction kinetic experiment was done to count in adsorption dye process, especially in the wastewater from textile industry. Dyes adsorption by using egg shell has equilibrium time at the 70 minutes after adsorption process. Then, the process has not a different significantly. The experiment data were fitted into the Langmuir and Freundlich isotherm. Based on adsorption data, the $\mathrm{R}^{2}$ value of Langmuir isotherm model was the highest, 0.9986 with adsorption capacity (As) 0.3589 and adsorption coefficient (Kb) 0.7962 . The adsorption kinetics of methylene blue on egg shell could be described by a pseudo second order model, with the regresion, $\mathrm{R}^{2}$ 0.9979 .

Keywords: kinetics, adsorption. egg shell, methylene blue

Metilen biru merupakan salah satu zat warna yang digunakan dalam industri. Senyawa ini merupakan senyawa organik yang berbahaya dan mengganggu ekosistem akuatik jika dibuang ke perairan. Oleh karena itu, perlu perlakuan khusus untuk mengurangi kepekatan warnanya, diantaranya melalui proses adsorpsi. Tujuan penelitian ini adalah untuk menganalisis kinetika reaksi adsorpsi metilen biru pada cangkang telur. Sintesis cangkang telur dianalisis menggunakan FTIR untuk mengetahui gugus fungsi di dalamnya. Uji kinetika reaksi dilakukan untuk dijadikan sebagai tolok ukur dalam penyerapan zat warna. Adsorben zat warna oleh cangkang telur memiliki waktu kesetimbangan pada menit $>70$. Evaluasi data eksperimen adsorpsi dilakukan pada model isoterm Langmuir dan Freundlich. Data adsorpsi yang sesuai adalah model isoterm Langmuir dengan nilai regresi tertinggi sebesar 0,9986; kapasitas adsorpsi (As) sebesar 0,3589 dan koefisien adsorpsi (Kb) sebesar 0,7962. Model kinetika reaksi adsorpsi metilen biru menggunakan cangkang telur cenderung pada pseudo orde 2 , dengan nilai $R^{2}$ 0,9979.

Kata Kunci: kinetika, adsorpsi, cangkang telur, metilen biru 


\section{Pendahuluan}

Zat warna berperan banyak dalam kehidupan, diantaranya industri tekstil dan makanan. Pewarna makanan merupakan pewarna yang aman bagi tubuh sehingga tidak dibutuhkan pengolahan lebih lanjut apabila limbah pengolahan dibuang ke lingkungan, sedangkan pewarna tekstil perlu dilakukan pengolahan lebih lanjut. Zat warna yang digunakan dalam industri tekstil merupakan pewarna sintetik. Pewarna sintetik tersebut merupakan senyawa aromatik kompleks dan perlu penanganan khusus jika mencemari lingkungan air. Limbah cair dari industri tekstil mengandung pewarna $8-20 \%$ karena efek dari proses pewarnaan (Noroozi, Sorial, Bahrami, \& Arami, 2008). Limbah cair berwarna dapat berakibat pada rusaknya tumbuhan sehingga ekosistemnya terganggu karena kontaminasi limbah cair berwarna tersebut (Uddin, Islam, Mahmud, \& Rukanuzzaman, 2009).

Metilen biru (MB) merupakan senyawa organik yang digunakan sebagai pewarna sintetik yang banyak digunakan dalam proses pewarnaan tekstil. Sisa pewarnaan tersebut menjadi limbah cairan yang berwarna. Beberapa metode pengolahan limbah cair yang dapat dilakukan diantaranya metode elektrokoagulasi (Merzouk et al., 2009), dengan mikroba (Jing et al., 2014), dan adsorpsi (Gomes, Piccin, \& Gutterres, 2016; Lin, Gung, Wu, \& Suen, 2015). Metode yang banyak digunakan adalah metode adsorpsi. Metode ini mudah dilakukan dan sumber yang digunakan banyak tersedia di alam. Metode adsorpsi banyak menggunakan karbon aktif. Akan tetapi, metode adsorpsi dengan karbon aktif memerlukan biaya yang mahal. Oleh karena itu, perlu dilakukan pencarian adsorben alternatif dengan harga yang lebih murah.

Cangkang telur merupakan limbah yang belum banyak dimanfaatkan. Cangkang telur dapat diperoleh dari industri makanan atau kue. Cangkang telur setelah kalsinasi mengandung 89,8\% $\mathrm{CaO}$ dan $0,01 \% \mathrm{MgO}$, dan bahan organik lainnya (Eletta, Ajayi, Ogunleye, \& Akpan, 2016). Cangkang telur banyak digunakan dalam berbagai aplikasi, misalnya sebagai katalis biodiesel (Piker, Tabah, Perkas, \& Gedanken, 2016) dan sebagai koagulan (Oladoja \& Aliu, 2009). Cangkang telur dapat digunakan sebagai adsorpsi logam-logam berbahaya dan limbah cair berwarna (Mittal, Teotia, Soni, \& Mittal, 2016). Oleh karena itu, dalam penelitian ini akan dilakukan studi kinetika pada adsorpsi cangkang telur pada zat warna metilen biru sehingga dapat diketahui kemampuan adsorpsinya terhadap metilen biru.

\section{Bahan dan metode}

\subsection{Bahan}

Bahan yang digunakan dalam penelitian ini adalah metilen biru (MB) 82\% (Gurr CERCISTAIN), dan cangkang telur.

\subsection{Preparasi adsorben}

Preparasi adsorben didasarkan pada penelitian Slimani et al (2014) dengan modifikasi. Cangkang telur dicuci bersih dan dikeringkan, kemudian dipanaskan hingga suhu $900^{\circ} \mathrm{C}$ selama 2 jam. Selanjutnya, dihaluskan dan diayak dengan ukuran 50 mesh. Pengujian karakteristik adsorben pada sampel cangkang telur dilakukan menggunakan FTIR Shimadzu-8201PC.

\subsection{Pengamatan adsorpsi metilen biru melalui metode Batch}

Penentuan penyerapan dilakukan dengan menimbang cangkang telur sebanyak $0,5 \mathrm{~g}$ dimasukkan ke dalam labu erlenmeyer yang berisi MB $5 \mathrm{mg} / \mathrm{L}$ sebanyak $100 \mathrm{~mL}$. Kemudian labu ditutup dengan aluminium foil dan dishaker dengan kecepatan $120 \mathrm{rpm}$ pada suhu $25^{\circ} \mathrm{C}$. Filrat yang dihasilkan dianalisis dengan spektrofotometer UVVis (T70 Double Beam) dengan serapan maksimum pada panjang gelombang $644 \mathrm{~nm}$. Jumlah zat warna yang teradsorpsi dengan berbagai waktu, $q_{t}(\mathrm{mg} / \mathrm{g})$, dihitung berdasarkan Persamaan 1.

$q_{t}=\frac{\left(C_{0}-C_{t}\right) V}{w}$

Dimana, $\mathrm{C}_{0}$ dan $\mathrm{C}_{\mathrm{t}}(\mathrm{mg} / \mathrm{L})$ adalah konsentrasi fasa cair MB pada awal dan pada waktu t. $V$ adalah volume larutan $(\mathrm{L})$, dan $w$ adalah massa adsorben (g).

Banyaknya MB yang teradsorpsi dihitung dengan Persamaan 2.

Serapan $(\%)=\frac{C_{0}-C_{e}}{C_{0}} \times 100 \%$

Dimana, $C_{0}$ merupakan konsentrasi sebelum teradsorpsi, dan $\mathrm{C}_{e}$ adalah konsentrasi setelah teradsorpsi. Mekanisme adsorpsi tergantung dari 
sifat fisik dan atau kimia dari material adsorben (Han, Wang, \& Ma, 2011; Tehrani-Bagha, Nikkar, Mahmoodi, Markazi, \& Menger, 2011). Penentuan mekanisme adsorpsi MB pada cangkang telur diperlukan analisis kinetika reaksi.

\subsection{Isotermis adsorpsi Langmuir dan Freundlich serta kapasitas adsorpsi}

Aktivitas adsorpsi MB maksimum pada cangkang telur ditentukan melalui adsorpsi Langmuir dan Freundlich yang disajikan pada Persamaan 3 dan 4.

$\frac{C_{e}}{q_{e}}=\frac{1}{K_{b} A_{s}}+\frac{C_{e}}{A_{s}}$

$\log q_{e}=\log K_{f}+\frac{1}{n} \log C_{e}$

Dimana, $\mathrm{C}_{\mathrm{e}}$ adalah konsentrasi MB di dalam cairan setelah teradsopsi, $q_{e}$ adalah berat adsorbat yang diserap per unit berat adsorben, $\mathrm{K}_{b}$ dan $\mathrm{K}_{f}$ merupakan koefisien adsorpsi, serta $A_{s}$ sebagai kapasitas atau daya adsorpsi maksimum.

\section{Hasil dan pembahasan}

\subsection{Karakterisasi adsorben}

Karakterisasi cangkang telur dilakukan uji Fourier Transform Infrared Spectroscopy (FTIR) untuk mengetahui gugus fungsi yang terbentuk. Berdasarkan Gambar 1, sinyal muncul pada panjang gelombang $3641,60 \mathrm{~cm}^{-1}$ sebagai $\mathrm{O}-\mathrm{H}$ stretching; $3448,72 \mathrm{~cm}^{-1}$ diduga muncul sebagai $\mathrm{OH}$ dari Si-OH yang didukung munculnya pada daerah 1635,64 cm-1. Hal ini dimungkinkan masih ada kadar air karena efek penyimpanan sedangkan daerah $825,53 \mathrm{~cm}^{-1}$ dan $871,82 \mathrm{~cm}^{-1}$ sebagai vibrasi Si-O- Daerah 2337,72 diindikasikan sebagai rentangan isosianat, $\mathrm{N}=\mathrm{C}=\mathrm{O}$, muncul dalam intensitas lemah. Adanya gugus tersebut dimungkinkan masih adanya $\mathrm{N}$ sisa dari protein yang membentuk dengan karbon serta oksigen dari udara (Zieleniewska et al., 2015). Vibrasi-vibrasi lain yang muncul pada daerah $2500-3000 \mathrm{~cm}^{-1}$ diindikasikan sebagai senyawa organik (Cave \& Pleistocene, 1996). Pada panjang gelombang 1400 - $1500 \mathrm{~cm}^{-1}$ diindikasikan sebagai vibrasi gugus Ca-O (Micic et al., 2015).

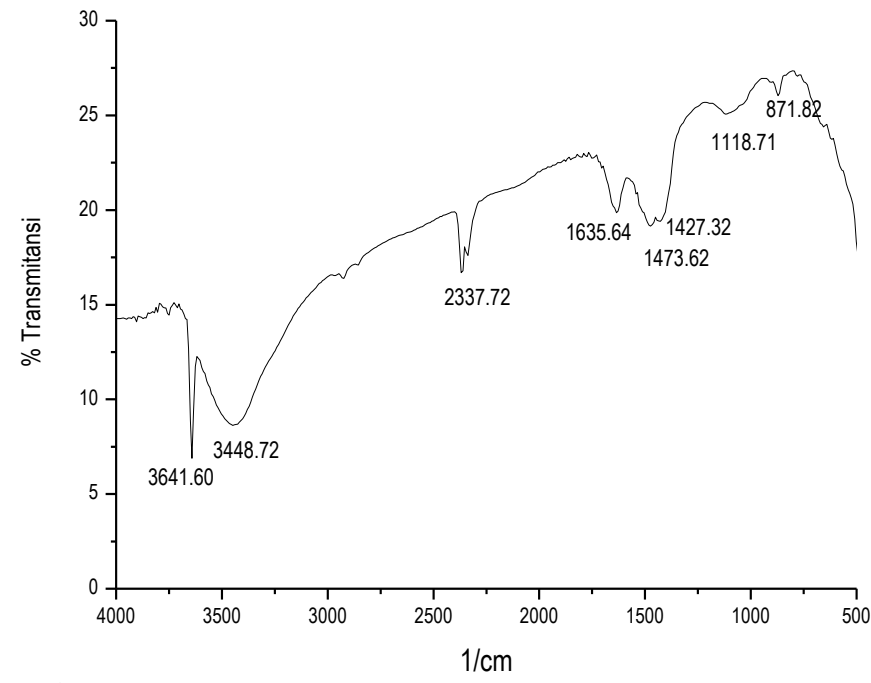

Gambar 1. Hasil analisis cangkang telur setelah kalsinasi

\subsection{Efek waktu kontak}

Konsentrasi dan waktu kesetimbangan ditentukan melalui adsorpsi pewarna MB terhadap cangkang telur sebagai fungsi waktu (Mall, Srivastava, \& Agarwal, 2006). Adsorpsi terjadi secara fisika, apabila yang banyak terserap adalah spesies adsorbat dalam interval waktu yang pendek sedangkan adsorpsi secara kimia terjadi apabila spesies adsorbat terserap dalam waktu yang cukup lama hingga pada kesetimbangan (Doğan, Özdemir, \& Alkan, 2007). Kemampuan adsorpsi dapat diamati pada Gambar 2. Adsorbat yang teradsorp berada pada kesetimbangan mulai waktu 70 dan 80 menit. Kondisi ini dimungkinkan adsorben telah berada pada kondisi jenuh.

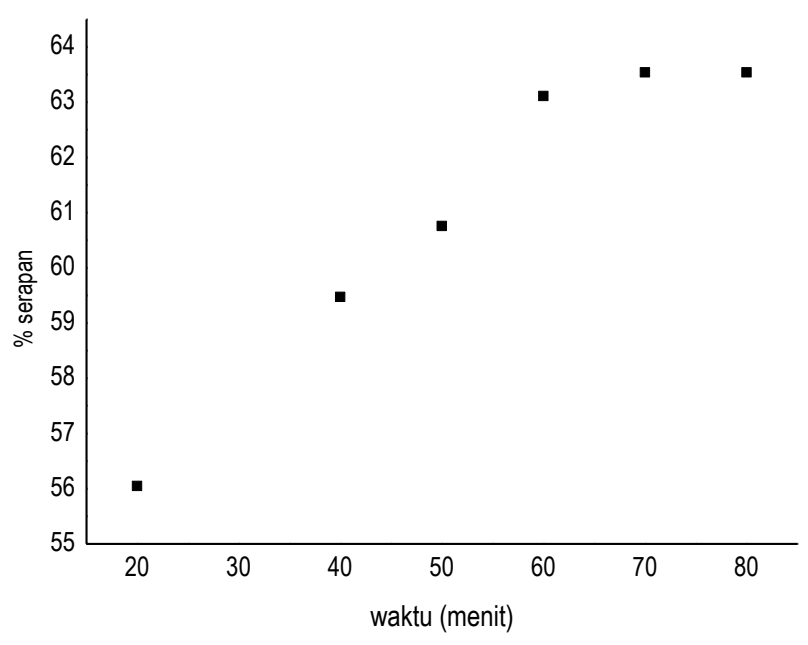

Gambar 2. Efek waktu kontak pada konsentrasi 5 $\mathrm{mg} / \mathrm{L}, \mathrm{T}=26^{\circ} \mathrm{C}$, cangkang telur $0,5 \mathrm{~g}$ 
Tidak adanya perubahan jumlah MB yang terserap menunjukkan adsorben tidak dapat menyerap kembali atau dalam keadaan setimbang. Pada interval waktu 50-60 menit merupakan kondisi perubahan menuju kesetimbangan. Bentuk kurva yang demikian dapat diindikasikan sebagai penutupan monolayer oleh zat warna pada permukaan cangkang telur (Aysan, Edebali, Ozdemir, Celik Karakaya, \& Karakaya, 2016)

\subsection{Kinetika adsorpsi}

\subsubsection{Kinetika reaksi pseudo orde 1}

Kinetika model pseudo orde 1 didapat dari persamaan kesetimbangan massa, yang mengasumsikan bahwa laju MB yang teradsorpsi terhadap waktu sebanding dengan kesetimbangan MB yang terserap pada berbagai waktu (qe - qt) yang diekspresikan pada Persamaan 5.

$$
\frac{d q_{t}}{d_{t}}=k_{1}\left(q_{e}-q_{t}\right)
$$

Jika diekspresikan dalam bentuk logaritma, dimana $\mathrm{t}=0$, $\mathrm{t}=\mathrm{t}$ hingga pada $\mathrm{t}=\mathrm{q}_{\mathrm{e}}$, maka Persamaan 5 menjadi Persamaan 6.

$$
\log \left(q_{e}-q_{t}\right)=\log q_{e}-\frac{k_{1}}{2,303} t
$$

Dimana $q_{t}$ dan $q_{e}$ adalah banyaknya MB yang terserap pada waktu $t$ dan saat setimbang, dan $\mathrm{k}_{1}$ merupakan konstanta laju reaksi.

Plot grafik $\log \left(q_{e}-q_{t}\right)$ terhadap $t$ menghasilkan grafik yang dapat dilihat pada Gambar 3 .

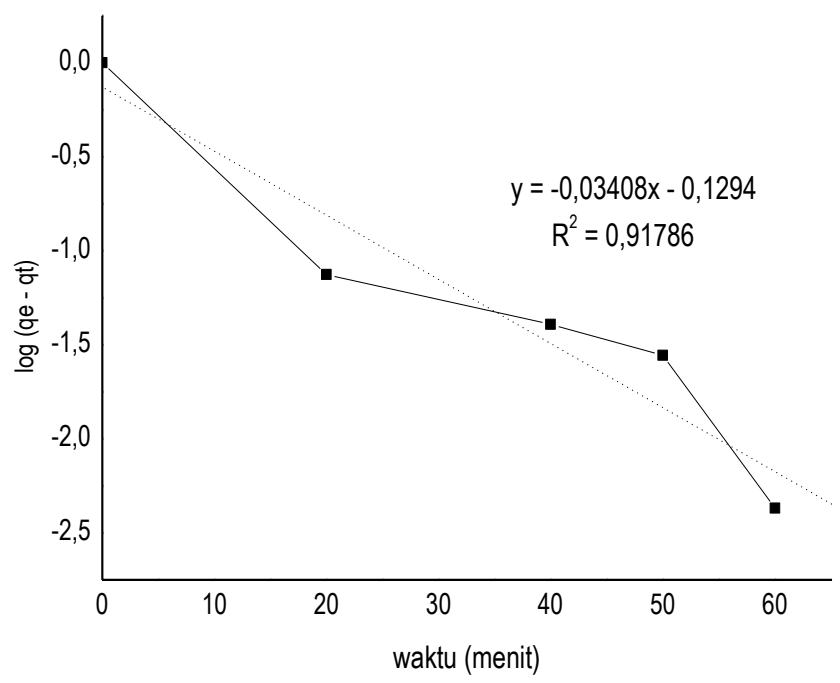

Gambar 3. Kinetika reaksi pseudo orde 1

\subsubsection{Kinetika reaksi pseudo orde 2}

Model kinetika reaksi pseudo orde 2 diasumsikan sebagai proses reaksi kimia-semu yang diekspresikan pada Persamaan 7 ,

$\frac{d q_{t}}{d_{t}}=k_{2}\left(q_{e}-q_{t}\right)^{2}$

Diintegralkan $t=0$ hingga $t=t$ dan $q=0$ dan $q=q_{e}$, menjadi Persamaan 8, dan jika diekspresikan dalam bentuk linier menjadi Persamaan 9 .

$$
\begin{aligned}
& \frac{1}{q_{e}-q_{t}}=\frac{1}{q_{e}}+k_{2} t \\
& \frac{t}{q_{t}}=\frac{1}{k_{2} q_{e}^{2}}+\frac{1}{q_{e}} t
\end{aligned}
$$

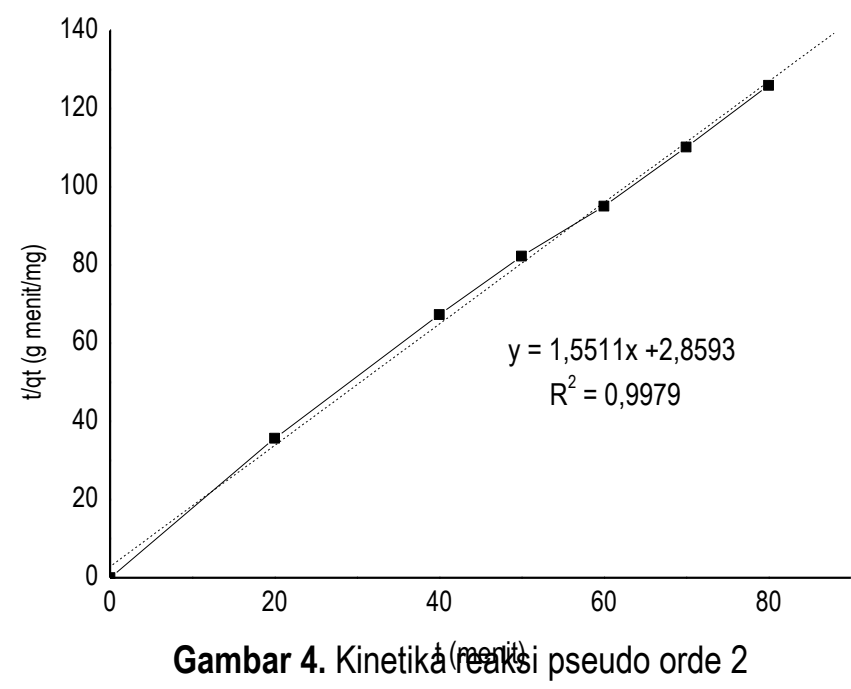

Model kinetika reaksi pseudo orde 1 pada menghasilkan nilai R sebesar 0,91786 (Gambar 3). Nilai kelinieran garis lebih kecil dibandingkan pada pseudo orde 2 (Gambar 4) yang memiliki nilai kelinieran sebesar 0,9979. Hal ini menunjukkan kinetika adsorpsi MB pada cangkang telur cenderung pada pseudo orde 2 .

\subsection{Isoterm adsorpsi}

\subsubsection{Isoterm Langmuir}

Model isoterm Langmuir digunakan untuk karakterisasi adsorpsi logam berat, pewarna, senyawa organik volatil, dan gas (Egashira, Tanabe, \& Habaki, 2012; Heidarizad \& Şengör, 2016; Tit, Said, Mahmoud, Kouser, \& Yamani, 2017; Ushiki, Sato, Ota, \& Inomata, 2015). Isoterm 
Langmuir mengasumsikan terjadi penyerapan zat warna pada permukaan, terjadi penutupan permukaan oleh zat warna MB (Athar, Farooq, Aslam, \& Salman, 2013). Berdasarkan hal tersebut, material adsorben disebut sebagai material homogen karena penyerapan terjadi di permukaan. Berdasarkan pengolahan data pada Gambar 5, kapasitas adsorpsi maksimumnya sebesar 0,3589 $\mathrm{mg} / \mathrm{g}$.

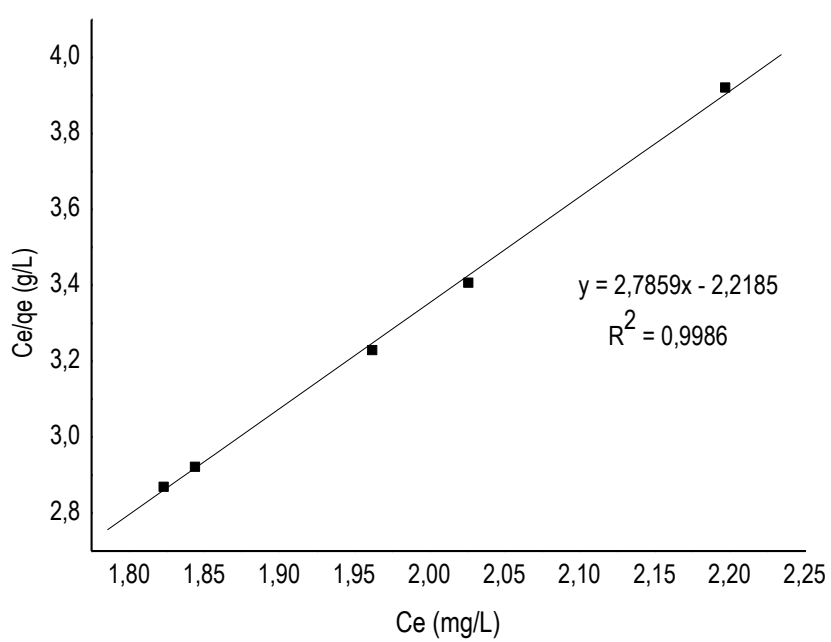

Gambar 5. Isoterm adsorpsi Langmuir

\subsubsection{Isoterm Freundlich}

Model isoterm Freundlich digunakan untuk mengamati kesetimbangan biosorben-adsorbat MB oleh cangkang telur. Nilai regresi yang dihasilkan sebesar $\mathrm{R}^{2}=0,9979$. Nilai yang didapat tidak jauh berbeda dengan isoterm Langmuir. Namun, apabila dilihat dari kelinierannya maka model isoterm yang sesuai adalah isotem Langmuir. Berdasarkan Tabel 1, nilai konstanta isoterm Freundlich sebesar 1,0548 .

\section{Tabel 1}

Konstanta Langmuir dan Freundlich

\begin{tabular}{lcc}
\hline \multicolumn{1}{c}{ Isoterm } & Konstanta & Nilai \\
\hline Langmuir & $\mathrm{As}$ & 0,3589 \\
& $\mathrm{~Kb}$ & 0,7962 \\
\hline Freundlich & $\mathrm{Kf}$ & 1,0548 \\
& $\mathrm{n}$ & 1,5057 \\
\hline
\end{tabular}

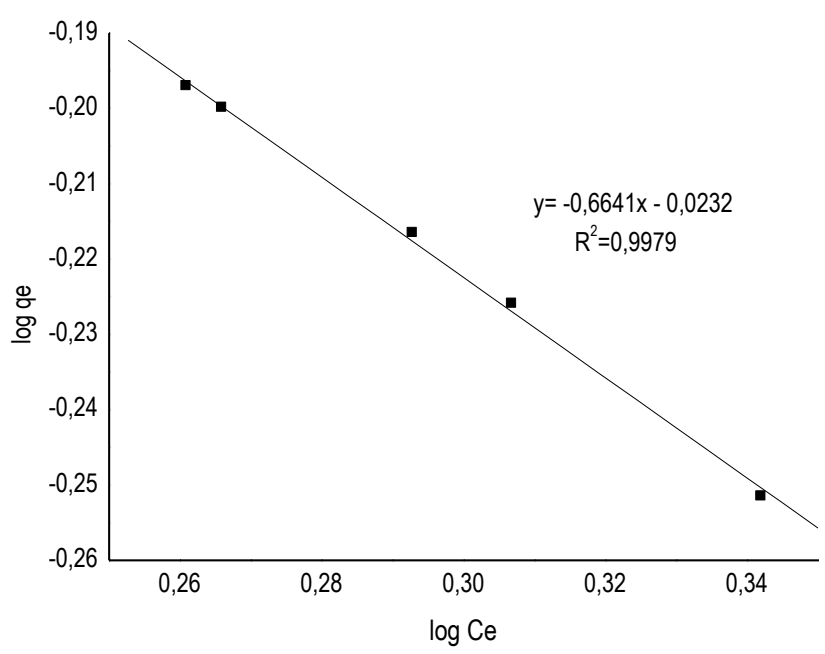

Gambar 6. Isoterm adsorpsi Freundlich

\section{Kesimpulan}

Kinetika reaksi adsorpsi pada cangkang telur menunjukkan kecenderungan ke arah pseudo orde 2 dengan nilai $R^{2}$ sebesar 0,9979 . Isoterm adsorpsi yang terbentuk adalah model isoterm Langmuir.

\section{Daftar pustaka}

Athar, M., Farooq, U., Aslam, M., \& Salman, M. (2013). Adsorption of $\mathrm{Pb}(\mathrm{II})$ ions onto biomass from Trifolium resupinatum: equilibrium and kinetic studies. Applied Water Science, 3(3), 665-672.

Aysan, H., Edebali, S., Ozdemir, C., Celik Karakaya, M., \& Karakaya, N. (2016). Use of chabazite, a naturally abundant zeolite, for the investigation of the adsorption kinetics and mechanism of methylene blue dye. Microporous and Mesoporous Materials, 235, 78-86.

Cave, L., \& Pleistocene, M. (1996). Lazaret Cave ( Middle Pleistocene ) in France. October, 126.

Doğan, M., Özdemir, Y., \& Alkan, M. (2007). Adsorption kinetics and mechanism of cationic methyl violet and methylene blue dyes onto sepiolite. Dyes and Pigments, 75(3), 701-713.

Egashira, R., Tanabe, S., \& Habaki, H. (2012). Adsorption of heavy metals in mine wastewater by Mongolian natural zeolite. Procedia Engineering, 42(August), 49-57. 
Eletta, O. A. A., Ajayi, O. A., Ogunleye, O. O., \& Akpan, I. C. (2016). Adsorption of cyanide from aqueous solution using calcinated eggshells: Equilibrium and optimisation studies. Journal of Environmental Chemical Engineering. https://doi.org/10.1016/j.jece.2016.01.020

Gomes, C. S., Piccin, J. S., \& Gutterres, M. (2016). Optimizing adsorption parameters in tannery-dye-containing effluent treatment with leather shaving waste. Process Safety and Environmental Protection, 99, 98-106.

Han, X., Wang, W., \& Ma, X. (2011). Adsorption characteristics of methylene blue onto low cost biomass material lotus leaf. Chemical Engineering Journal, 171(1), 1-8.

Heidarizad, M., \& Şengör, S. S. (2016). Synthesis of graphene oxide/magnesium oxide nanocomposites with high-rate adsorption of methylene blue. Journal of Molecular Liquids.

https://doi.org/10.1016/j.molliq.2016.09.049

Jing, H., Mezgebe, B., Aly Hassan, A., SahleDemessie, E., Sorial, G. A., \& BennettStamper, C. (2014). Experimental and modeling studies of sorption of ceria nanoparticle on microbial biofilms. Bioresource Technology, 161, 109-117.

Lin, C. H., Gung, C. H., Wu, J. Y., \& Suen, S. Y. (2015). Cationic dye adsorption using porous composite membrane prepared from plastic and plant wastes. Journal of the Taiwan Institute of Chemical Engineers, 51, 119-126.

Mall, I. D., Srivastava, V. C., \& Agarwal, N. K. (2006). Removal of Orange-G and Methyl Violet dyes by adsorption onto bagasse fly ash - Kinetic study and equilibrium isotherm analyses. Dyes and Pigments, 69(3), 210-223.

Merzouk, B., Gourich, B., Sekki, A., Madani, K., Vial, C., \& Barkaoui, M. (2009). Studies on the decolorization of textile dye wastewater by continuous electrocoagulation process. Chemical Engineering Journal. https://doi.org/10.1016/j.cej.2008.10.018

Micic, R. D., Bosnjak Kiralj, M. S., Panic, S. N., Tomic, M. D., Jovic, B. D., \& Boskovic, G. C. (2015). Activation temperature imposed textural and surface synergism of $\mathrm{CaO}$ catalyst for sunflower oil transesterification. Fuel, 159, 638-645.
Mittal, A., Teotia, M., Soni, R. K., \& Mittal, J. (2016). Applications of egg shell and egg shell membrane as adsorbents: A review. Journal of Molecular Liquids. https://doi.org/10.1016/j.molliq.2016.08.065

Noroozi, B., Sorial, G. A., Bahrami, H., \& Arami, M. (2008). Adsorption of binary mixtures of cationic dyes. Dyes and Pigments. https://doi.org/10.1016/j.dyepig.2007.02.00 3

Oladoja, N. A., \& Aliu, Y. D. (2009). Snail shell as coagulant aid in the alum precipitation of malachite green from aqua system. Journal of Hazardous Materials, 164(2-3), 14961502.

Piker, A., Tabah, B., Perkas, N., \& Gedanken, A. (2016). A green and low-cost room temperature biodiesel production method from waste oil using egg shells as catalyst. Fuel, 182, 34-41.

Slimani, R., El Ouahabi, I., Abidi, F., El Haddad, M., Regti, A., Laamari, M. R., ... Lazar, S. (2014). Calcined eggshells as a new biosorbent to remove basic dye from aqueous solutions: Thermodynamics, kinetics, isotherms and error analysis. Journal of the Taiwan Institute of Chemical Engineers, 45(4), 1578-1587.

Tehrani-Bagha, A. R., Nikkar, H., Mahmoodi, N. M., Markazi, M., \& Menger, F. M. (2011). The sorption of cationic dyes onto kaolin: Kinetic, isotherm and thermodynamic studies. Desalination, 266(1-3), 274-280.

Tit, N., Said, K., Mahmoud, N. M., Kouser, S., \& Yamani, Z. H. (2017). Ab-initio investigation of adsorption of $\mathrm{CO}$ and $\mathrm{CO}_{2}$ molecules on graphene: Role of intrinsic defects on gas sensing. Applied Surface Science, 394, 219-230.

Uddin, M. T., Islam, M. A., Mahmud, S., \& Rukanuzzaman, M. (2009). Adsorptive removal of methylene blue by tea waste. Journal of Hazardous Materials. https://doi.org/10.1016/j.jhazmat.2008.07.1 31

Ushiki, I., Sato, Y., Ota, M., \& Inomata, H. (2015). Adsorption equilibria of volatile organic compounds on various adsorbents in supercritical carbon dioxide: Measurement and analysis by the Dubinin-Astakhov equation. Fluid Phase Equilibria, 420, 5867. 
Zieleniewska, M., Leszczyński, M. K., Szczepkowski, L., Bryśkiewicz, A., Małgorzata, K., Bień, K., \& Ryszkowska, J. (2015). Development and applicational evaluation of the rigid polyurethane foam composites with egg shell waste. Polymer Degradation and Stability, 132, 78-86. 